\title{
Comment on 'The Global Impacts of Extreme Sea-Level Rise: A Comprehensive Economic Assessment'
}

\author{
Richard S. J. Tol ${ }^{1,2,3,4}$ - Robert J. Nicholls ${ }^{5}$ - Sally Brown ${ }^{5}$ - Jochen Hinkel ${ }^{6}$. \\ Athanasios T. Vafeidis $^{7}$. Tom Spencer ${ }^{8}$. Mark Schuerch ${ }^{7}$
}

Accepted: 18 December 2015 / Published online: 11 March 2016

(C) The Author(s) 2016. This article is published with open access at Springerlink.com

\begin{abstract}
Pycroft et al. (Environ Resour Econ 1-29, 2015) used incorrect and outdated data to study the economic impact of sea level rise. They misinterpret some of their input data, and fail to exploit the strengths of their computable general equilibrium model and previously developed methods to study impacts and adaptation.
\end{abstract}

Keywords Climate change $\cdot$ Sea level rise $\cdot$ Computable general equilibrium $\cdot$ Adaptation

Pycroft et al. (2015) analysed global economic losses due to sea-level rise using a Computable General Equilibrium (CGE) model based on impact data generated from the Dynamic Interactive Vulnerability Assessment (DIVA). We, part of the team who developed the DIVA model, have concerns regarding part of the literature review, the use of data generated from the DIVA model and how it is communicated in the paper. We also have concerns about how the data were used in the CGE. We had limited communication with the team prior to their submission, and were not involved in the review process of the paper.

In the fast-moving research field of global environmental change, we find much of the literature review is of historical interest only ( $80 \%$ of references are pre-2012). In places it is incorrect. For example, the work of Nicholls et al. (2008) is claimed to principally use

$凶$ Richard S. J. Tol

r.tol@sussex.ac.uk

1 Department of Economics, University of Sussex, Jubilee Building, Falmer BN1 9SL, UK

2 Institute for Environmental Studies and Department of Spatial Economics, Vrije Universiteit Amsterdam, Amsterdam, The Netherlands

3 Tinbergen Institute, Amsterdam, The Netherlands

4 CESifo, Munich, Germany

5 Faculty of Engineering and the Environment, University of Southampton, Highfield, Southampton SO17 1BJ, UK

6 Global Climate Forum, Berlin, Germany

7 Institute of Geography, 'The Future Ocean' Excellence Cluster, University of Kiel, Kiel, Germany

8 Cambridge Coastal Research Unit, University of Cambridge, Cambridge, UK 
the DIVA model, whereas in fact the FUND model was used-the models are very different. In particular, we find the discussion of sea level rise scenarios outdated as much of the discussion relates back to IPCC AR4 (Meehl et al. 2007), with the latest reference quoted as 2010. Since 2010 and before paper acceptance, there have been considerable advances in the understanding of ice sheet mass balances and improvements in ice sheet modelling, expertly reviewed in Hanna et al. (2013), and these advances underpin new estimates of global sea level rise (Church et al. 2013).

The input data of Pycroft et al. (2015) relies on the unpublished report of Brown et al. (2011) (or a derivative thereof) generated in the EU FP7 project ClimateCost. Brown et al. used scenarios from Pardaens et al. (2011). Neither ClimateCost nor Pardaens are cited in their paper. We find the scenarios referred to difficult to understand. For example, Pycroft et al. (2015) remark about uniform sea-level rise in 2085 "relative to preindustrial levels are $0.47,1.12$ and $1.75 \mathrm{~m}$ in the A1B, Rahm and High scenarios, respectively". For A1B, the data from HadGEM2-A0 in Pardaens et al. (2011) is relative to a 1980-1999 baseline. This scenario is not a uniform rise in sea-level, but a spatially differentiated one. We cannot reproduce the latter two (uniform) sea-level rise scenarios. Further confusion is noted where scenarios were projected to ' 1.4 and $2 \mathrm{~m}$ by 2100 '. With respect to a 1990 baseline, the former (Rahm) is not correct, whilst the latter (High) is.

In Pycroft et al. (2015), there are gaps in understanding of DIVA's processes, output parameters, adaptation and assumptions. Economic models using DIVA have been cited, rather than a full set of references relating the model development (Hinkel 2005; Hinkel and Klein 2009; Hinkel et al. 2014, 2013; McFadden et al. 2007a, b; Vafeidis et al. 2008). The DIVA model is continually under improvement, with the latest papers superseding the older work of Brown et al. (2011). Elsewhere, relative land level change is described incorrectly: It follows the data of (Peltier 2000a, b), rather than relate to the sea-level rise scenarios.

Pycroft et al. (2015) also overlook a crucial assumption in DIVA, which draws on earlier work by Yohe (1990) and Yohe et al. (1996). Pycroft et al. (2015) only consider scenarios without public adaptation, that is, without additional coastal protection (dikes, nourishment). However, in the absence of public adaptation, private adaptation becomes more important. DIVA abstracts from changes in storminess and conceptualizes sea level rise as a gradualand therefore predictable_-process. That means that buildings and infrastructure will be fully depreciated just before inundation. Property markets will adjust so that the impact of sea level rise falls on the properties with the lowest value. In other words, sea-level rise will take from the endowment of agricultural land - rather than from invested capital as assumed by Pycroft et al. (2015). Thus, economic impacts are greatly exaggerated.

Table 1 lacks clarity. We believe it represents annual costs in the 2080s without further upgrades to the coastal protection in 2005, as assumed in DIVA. While the estimated damages are the correct order of magnitude, we cannot reproduce these figures.

With regard to the economic modelling, in Section 4.2, the authors also describe how the impacts of sea level rise affect the economy. This is quite different from how it is done in other papers (Bigano et al. 2008; Bosello et al. 2012a, b, 2007; Darwin and Tol 2001; Eboli et al. 2010; Roson and van der Mensbrugghe 2012) and it is hard to understand why Pycroft et al. (2015) made the choices they made.

Particularly, in Table 1 and in Section 4, Pycroft et al. (2015) interpret the welfare loss due to forced migration as a shock to consumption. It is not: It is a shock to the immaterial part of well-being (Fankhauser and Tol 2005). This part of the impact of sea level rise does not directly affect the real economy. At the same time, Pycroft et al. (2015) ignore the real economic effects of migration, that is, the relocation of consumers and workers, the working hours lost in transit, the mismatch of skills and jobs, and remittances. 
The other impacts of sea level partly reduce consumption (70\%) and partly reduce the capital stock $(30 \%)$. The language in Section 4.2 suggests that these reductions are uniform rather than sector-specific. This is an unnecessary simplification. We have a good idea of what economic sectors are located near the coast and therefore would be disproportionally hit by sea level rise.

It is not clear why Pycroft et al. (2015) impose shocks on consumption and capital. Erosion implies land loss. As argued above, it stands to reason that agriculture would absorb most of the shock. In the context of the CGE, this is a shock not to consumption or capital but rather to the endowment of land. Floods imply capital destruction and service interruptions. These are shocks to the capital stock and total factor productivity, respectively. By imposing shocks on consumption directly, Pycroft et al. (2015) again disallow private adaptation: The costs of production in the affected sectors and countries would rise with the level of the sea. The demand, both final and intermediate, for their goods and services would thus change, and so would the regional and sectoral composition of total expenditure. This change in the composition of consumption, ignored by Pycroft, reduces the welfare impact.

In sum, the paper by Pycroft et al. (2015) is methodologically a step backward. Its application value is limited as the authors were not particularly careful with the numbers and as the impacts of sea level rise were exaggerated.

Open Access This article is distributed under the terms of the Creative Commons Attribution 4.0 International License (http://creativecommons.org/licenses/by/4.0/), which permits unrestricted use, distribution, and reproduction in any medium, provided you give appropriate credit to the original author(s) and the source, provide a link to the Creative Commons license, and indicate if changes were made.

\section{References}

Bigano A, Bosello F, Roson R, Tol RJ (2008) Economy-wide impacts of climate change: a joint analysis for sea level rise and tourism. Mitig Adapt Strateg Glob Change 13(8):765-791

Bosello F, Roson R, Tol RSJ (2007) Economy-wide estimates of the implications of climate change: sea level rise. Environ Resour Econ 37(3):549-571

Bosello F, Eboli F, Pierfederici R (2012a) Assessing the economic impacts of climate change. Review of environment energy and economics 1-9

Bosello F, Nicholls RJ, Richards J, Roson R, Tol RSJ (2012) Economic impacts of climate change in Europe: sea-level rise. Clim Change 112(1):63-81

Brown S, Nicholls RJ, Vafeidis A, Hinkel J, Watkiss P (2011) The impacts and economic costs of sea-level rise in Europe and the costs and benefits of adaptation. Summary of results from the EC RTD climatecost project. In: Watkiss P (ed) The climatecost project. Final report. Volume 1: Europe. Stockholm Environment Institute, Sweden

Church JA, Clark PU, Cazenave A, Gregory JM, Jevrejeva S, Levermann A, Merrifield MA, Milne GA, Nerem RS, Nunn PD, Payne AJ, Pfeffer WT, Stammer D, Unnikrishnan AS (2013) Sea level change. In: Stocker TF, Qin D, Plattner G-K, Tignor M, Allen SK, Boschung J, Nauels A, Xia Y, Bex V, Midgley PM (eds) Climate change 2013: The physical science basis. Contribution of working group i to the fifth assessment report of the intergovernmental panel on climate change. Cambridge University Press, Cambridge, pp 1137-1216

Darwin RF, Tol RSJ (2001) Estimates of the economic effects of sea level rise. Environ Resour Econ 19(2):113129

Eboli F, Parrado R, Roson R (2010) Climate-change feedback on economic growth: explorations with a dynamic general equilibrium model. Environ Dev Econ 15(5):515-533

Fankhauser S, Tol RSJ (2005) On climate change and economic growth. Resour Energy Econ 27(1):1-17

Hanna E, Navarro FJ, Pattyn F, Domingues CM, Fettweis X, Ivins ER, Nicholls RJ, Ritz C, Smith B, Tulaczyk S, Whitehouse PL, Zwally HJ (2013) Ice-sheet mass balance and climate change. Nature 498(7452):51-59

Hinkel J (2005) DIVA: an iterative method for building modular integrated models. Adv Geosci 4:45-50 
Hinkel J, Nicholls RJ, Tol RSJ, Wang ZB, Hamilton JM, Boot G, Vafeidis AT, McFadden L, Ganopolski A, Klein RJT (2013) A global analysis of erosion of sandy beaches and sea-level rise: an application of DIVA. Glob Planet Change 111:150-158

Hinkel J, Lincke D, Vafeidis AT, Perrette M, Nicholls RJ, Tol RSJ, Marzeion B, Fettweis X, Ionescu C, Levermann A (2014) Coastal flood damage and adaptation costs under 21st century sea-level rise. Proc Natl Acad Sci USA 111(9):3292-3297

Hinkel J, Klein RJT (2009) Integrating knowledge to assess coastal vulnerability to sea-level rise: the development of the DIVA tool. Glob Environ Change Hum Policy Dimens 19(3):384-395

McFadden L, Nicholls RJ, Vafeidis A, Tol RSJ (2007) A methodology for modeling coastal space for global assessment. J Coast Res 23(4):911-920

McFadden L, Spencer T, Nicholls RJ (2007) Broad-scale modelling of coastal wetlands: what is required? Hydrobiologia 577:5-15

Meehl GA, Stocker TF, Collins WD, Friedlingstein P, Gaye T, Gregory JM, Kitoh A, Knutti R, Murphy JM, Noda A, Raper SCB, Watterson IG, Weaver AJ, Zhen Z-C (2007) Global Climate Projections. In: Qin D, Manning M, Chen Z, Marquis M, Averyt K, Tignor MMB, Miller HL (eds) Climate change 2007: The physical science basis - contribution of working group I to the fourth assessment report of the intergovernmental panel on climate change. Cambridge University Press, Cambridge, pp 747-847

Nicholls RJ, Tol RSJ, Vafeidis AT (2008) Global estimates of the impact of a collapse of the West Antarctic ice sheet: an application of FUND. Clim Change 91(1-2):171-191

Pardaens AK, Lowe JA, Brown S, Nicholls RJ, de Gusmao D (2011) Sea-level rise and impacts projections under a future scenario with large greenhouse gas emission reductions. Geophys Res Lett 38: L12604

Peltier WR (2000a) Global glacial isostatic adjustment and modern instrumental records of relative sea level history. In: Douglas BC, Kearny MS, Leatherman SP (eds) Sea level rise; history and consequences. Academic Press, San Diego, pp 65-95

Peltier WR (2000b) ICE4G (VM2) glacial isostatic adjustment corrections. In: Douglas BC, Kearny MS, Leatherman SP (eds) Sea level rise; history and consequences: on CD. Academic Press, San Diego

Pycroft J, Abrell J, Ciscar J-C (2015) The global impacts of extreme sea-level rise: a comprehensive economic assessment. Environ Resour Econ 1-29. doi:10.1007/s10640-014-9866-9

Roson R, van der Mensbrugghe D (2012) Climate change and economic growth: impacts and interactions. Int J Sustain Econ 4(3):270-285

Vafeidis AT, Nicholls RJ, McFadden L, Tol RSJ, Hinkel J, Spencer T, Grashoff PS, Boot G, Klein RJT (2008) A new global coastal database for impact and vulnerability analysis to sea-level rise. J Coast Res 24(4):917-924

Yohe GW (1990) The cost of not holding back the sea: toward a national sample of economic vulnerability. Coast Manag 18:403-431

Yohe GW, Neumann JE, Marshall P, Ameden H (1996) The economic costs of sea level rise on US coastal properties. Clim Change 32:387-410 